Jatp. J. M. Sc. \& Biol., 15, 111-113, 1962

\title{
AN ARIZONA SEROTYPE $(1,33: 24: 25: 39: 40)$ POSSESSING FOUR NATURALLY OCCURRING, REVERSIBLE H PHASES
}

\author{
*MARY A. FIFE, *PHILIP R. EDWARDS \\ AND **RIICHI SAKAZAKI \\ *Communicable Disease Center, Public Health Service, U. S. Department \\ of Health, Education and Welfare, Atlanta, Ga.; \\ **National Institute of Health, Tokyo
}

(Received : April 20th, 1962)

The occurrence of multiple phases and complex phases in Enterobacteriaceae was reviewed by Fife et al. (1961), Edwards, Sakazaki and Kato (1962) and Edwards, McWhorter and Douglas (1962). To the present, three Arizona serotypes which possessed three reversilbe flageller phases have been described and one culture of Salmonella mikawashima which exhibited four reversible flagellar phases has been recognized. Sakazaki, Tsujimoto, Edwards and Fife (1962) detected three additional triphasic Arizona cultures. Aside from these observations no cultures of Enterobacte riaceae have been encountered which contained more than two naturally occurring reversible $\mathrm{H}$ phases. The purpose of the present paper is to describe an Arizona type in which four distinct flagellar phases were detected.

\section{MATERIALS AND METHODS}

The organism to be described, 2038-60 (CDC 3062-61), was isolated from the feces of an apparently normal snake (Agkistrodon halys blomhaffi). The methods used in the biochemical and serological study of the organism were those described by Edwards and Ewing (1962). The cultures and sera used in the study were the standard strains of the Arizona group and sera derived from them.

\section{RESULTS}

The organism was a motile bacterium, the cultural and biochemical properties of which were typical of the family Enterobacteriaceae. Indol was not produced, the methyl red test was positive and the Voges-Proskauer test negative, growth occurred promptly on Simmons' citrate agar, hydrogen sulfide was produced, urease and phenylalanine deaminase were not formed, no growth occurred in Moeller's KCN medium. Lysine and ornithine decarboxylase and arginine dihydrolase were produced, and gelatin was liquefied slowly.

When tested by the method of Kauffmann and Petersen (1956) positive results were obtained in D-tartrate, citrate, mucate, and malonate broths after 48 hours incubation. Acid and gas were produced promptly from glucose, arabinose, xylose, maltose, sucrose, trehalose, raffinose, mannitol, and sorbitol. Lactose was fermented after 2 days, 坂崎利一（国立予防衛生研究所細菌第一部） 
rhamnose after 3 days, and cellobiose after 8 days incubation. Dulcitol, inositol, adonitol and salicin were not fermented. These reactions differed from the usual biochemical properties displayed by the Arizona group in that sucrose and raffinose were fermented.

When tested with Arizona $\mathrm{O}$ sera, the organism reacted strongly with serum for $\mathrm{O}$ group 1, 33 and with factor 33 serum. In absorption tests culture 2038-60 removed all agglutinins from 1, 33 serum. When tested with Arizona $\mathrm{H}$ sera, agglutination occurred only in $\mathrm{H} 40$ serum. The $\mathrm{H}$ antigen designated 40 in the Arizona group is divisible into two distinct entities designated as $40 \mathrm{a}, 40 \mathrm{~b}$ and $40 \mathrm{a}, 40 \mathrm{c}$ respectively. The relationships of these antigens and the reactions of the $\mathrm{H} 40$ phase of 2038-60 are given in Table 1, from which it can be seen that 2038-60 contained antigen 40a, $40 \mathrm{c}$.

Table 1. The reactions of the $\mathrm{H} 40$ phase of 2038-60 in

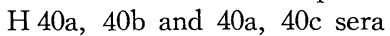

\begin{tabular}{|c|c|c|c|}
\hline \multirow[b]{2}{*}{ Sera } & \multicolumn{3}{|c|}{ Antigens } \\
\hline & $\begin{array}{c}2907-58 \\
(40 \mathrm{a}, 40 \mathrm{~b})\end{array}$ & $\begin{array}{c}2253-60 \\
(40 \mathrm{a}, 40 \mathrm{c})\end{array}$ & $\begin{array}{c}2038-60 \\
(40 \mathrm{a}, 40 \mathrm{c})\end{array}$ \\
\hline \multicolumn{4}{|l|}{$2907-58(40 a, 40 b)$} \\
\hline Unabsorbed & 6400 & 3200 & 3200 \\
\hline Absorbed by $2038-60$ & 800 & $<100$ & $<100$ \\
\hline \multicolumn{4}{|l|}{$2253-60(40 a, 40 c)$} \\
\hline Unabsorbed & 3200 & 6400 & 6400 \\
\hline \multirow{2}{*}{$\begin{array}{r}\text { Absorbed by } \begin{array}{r}2907-58 \\
2038-60\end{array}\end{array}$} & $<100$ & 200 & 200 \\
\hline & $<100$ & $<100$ & $<100$ \\
\hline
\end{tabular}

When the organism was placed in semisolid medium which contained $\mathrm{H} 40$ serum it spread rapidly through the medium. From the spreading growth was isolated a form which was agglutinated to the titre of Arizona H 24 serum. The H 24 phase then was placed in semisolid medium containing $\mathrm{H} 24$ serum to produce reversion to the H 40 phase. Again the organism spread through the medium but the phase recovered from the spreading growth agglutinated not with $\mathrm{H} 40$ serum, but with $\mathrm{H} 25$ serum. In order to determine whether $\mathrm{H} 40$ or $\mathrm{H} 24$ would emerge from the $\mathrm{H} 25$ phase, the organism was inoculated into semisolid medium which contained H 25 serum. From the migrating growth a culture was obtained which was agglutinated neither by $\mathrm{H} 24$ nor $\mathrm{H} 40$ serum but was agglutinated to the titre of $\mathrm{H} 39$ serum.

When the whole culture or single colonies were inoculated into semisolid medium to which had been added sera for all of the four $\mathrm{H}$ phases no migration of the organism through the medium occurred, indicating that no further phases were present. All four of the flagellar phases recognized possessed $O$ antigen 1,33. After four distinct and unrelated $\mathrm{H}$ phases had been recovered from the culture it was suspected that a mixture of two diphasic types were present. The work then was repeated with single colony isolations and comparable results were obtained. At this point three single colonies of each of the four phases were isolated and tested for their ability to give rise to each of the other three phases. Through growth in appropriate combinations of sera it was demonstrated that colonies of the $\mathrm{H} 24$ phase would yield $\mathrm{H} 25$, H 39, and H 40 phases. Comparable results were obtained with the single colonies of 
the $\mathrm{H} 25, \mathrm{H} 39$, and $\mathrm{H} 40$ phases. With the exception of slight difficulty encountered in obtaining the $\mathrm{H} 24$ phase from $\mathrm{H} 40$ colonies, all changes in phase occurred readily and apparently such changes could be continued indefinitely.

In the examination of single colonies of the whole culture without recourse to change of phase by serum, colonies of the $\mathrm{H} 40$ and $\mathrm{H} 39$ phases were found. No special search was made for $\mathrm{H} 24$ and $\mathrm{H} 25$ colonies since these phases are well known Arizona $\mathrm{H}$ antigens which occur naturally in many serotypes (Edwards and Ewing, 1962). H 39 and H 40 phases also occur naturally in other serotypes but they have not been found so frequently as $\mathrm{H} 24$ and $\mathrm{H} 25$.

No cross agglutination occurred among the four $\mathrm{H}$ phases. The reactions of the $\mathrm{H} 40$ phase were given in Table 1 . The $\mathrm{H} 24, \mathrm{H} 25$ and $\mathrm{H} 39$ phases each was agglutinated to the titre of the respective serum used for the detection of those antigens. In absorption tests the $\mathrm{H} 25$ and $\mathrm{H} 39$ phases effected a complete removal of $\mathrm{H}$ agglutinins from the corresponding serum. The $\mathrm{H} 24$ phase reduced the titre of $\mathrm{H} 24$ serum from $1-12,800$ to 1 to 100 .

\section{SUMMARY}

An Arizona culture which possesses four distinct flagellar phases is described. The organism, which was isolated from a snake, is represented by the antigenic formula $1,33: 24: 25: 39: 40 \mathrm{a}, 40 \mathrm{c}$. The four flagellar phases found in the culture all occur naturally in other Arizona serotypes. Each of the four phases recognized could be transformed to any of the other three at will by cultivation in appropriate sera.

\section{REFERENCES}

EDWARds, P. R. \& EWING, W. H. (1962): Identification of Enterobacteriaceae. 2nd Edition. Burgess Pub. Co., Minneapolis.

Edwards, P. R., McWhorter, A. C. \& Douglas, G. W. (1962) : A culture of Salmonella infantis of complex antigenic constitution. J. Bact., in press.

EDWARDS, P. R., SAKAZAKI, R. \& KATO, I. (1962): The natural occurrence of four reversible flagellar phases in cultures of Salmonella mikawashima. Jour. Bact., in press.

Fife, M. A., Edwards, P. R., Sakazaki, R., Nozawa, M. \& Murata, M. (1960) : The occurrence of three flagellar phases in Arizona serotypes. Jap. J. M. Sc. \& Biol., 13, 173-178.

KAUfFMAnN, F. \& PETERSEN, A. (1956): The biochemical group and type differentiation of Enterobacteriaceae by organic acids. Acta pathol. et microbiol. Scand., 38, 481-491.

SAKAzAki, R., Tsujimoto, N,, Edwards, P. R. \& Fite, M. A. (1962): Three triphasic Arizona serotypes $(21: 23: 30: 42 ; 26: 23: 30: 40 ;$ and $1,33: 24: 25: 39)$. Jap. J. M. Sc. \& Biol., 15, 107-109. 